\title{
騒音下に打ける慢性中耳炎耳の高音聴力低下に ついての考察
}

\author{
大阪市立大学医学部耳鼻咽喉科学教室 (主任：山本 馨教授)

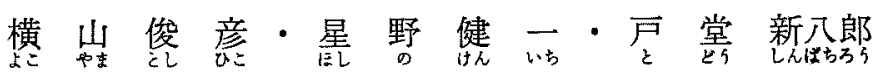

\section{I 緒言}

伝音系障害が騒音性難聴に詨して耳栓装着のような制 音効果によつて防禦的に作用するであるらことは想像出 来る。しかし実際に当つては，中耳伝音障害耳が騒音に よる内耳障害にとのような効果を有するかについては， 未だ報告者の意見が一致していないのが現状である。

その理由として, 本問題には, 伝音疾患の種類と程 度, 中耳炎自体による内耳障害の併発, 職場騒音の強さ と性質, 個人差, 生理的聴力損失など種々の外的および 内的要因が関与する上に，症例が極めて少ないことが举 げられる，従つて，既存の漫性中耳炎を有する騒音下従 業員の高音聴力低下が如何なる意味を有するかについて 判定を下すことは必ずしも容易でない。

慢性中耳炎の騒音性難聴に対する影響をを気導聴力損 失のみで評価した報告者は少なくないが，長年存続する 中耳疾患例では，騒音の存在有無に関㐿なく，気導一骨 遵差 (airbone gap) が低音城のみならず高音域にわたつ て生ずる可能性が多いこと，骨尊聴力は感音系機能を反 映することの 2 点から,この評価尺度には高音域骨導聴 力の損失の大小を重視すべきである。また，伝音疾患と 騒音性内耳疾患との関連性を追求するには, 前述の如く 多数の要因が関与するので，本問題を解明するには多数 の症例をもつて要因別に各データを分析すると共に，他 辛では同一症例について聴力変化を長年にわたり継続的 に追跡する必要があるが，実際上，種々の問題があつて 実現困難なことが多い

私共は騒音性難聴の個人差を考慮して，一側耳洁膜 ほ心゙正常で騷音による内耳障害と思われる難聴が認めら れ，他側耳のみが鼓膜に古くから存在する明らかな変 化，例えば穿孔，㓔痕などの純䊉な伝音難聴あるい混 合性難聴（内耳性障害は騒音に帰因すると推定される難 聴) 有する症例について，両側耳に対する騒音の影響 を気導と骨尊の相互の関係から比較検討すると共に, 上 述の各要員との関係について種々考察を加えた。 また他
方, 本研究対象者から過古 6 年前の才ージオグラムと比 較し得た者について, その聴力の変化より健側鼓膜耳と 患側鼓膜耳の難聴進展の度合を比較観察した。

\section{II 研究対象者と研究方法}

私共は某造船工場, 某自動車製造工場, 某鉄工所, 大 阪某地区各種機械工場における85ホン以上の騷音職場に 常勤する従業員, 合計 635 名の中から, 一側鼓膜異常, 他側鼓膜ほ $ふ$ 正常な者16名を本研究対象者とした。

なお，鼓膜異常と注穿孔と版痕を示し，溷溞，内陌， 石死沈看などは除外した．また，片側性鼓膜異常者であ つても，下記の項目に該当する者は本研究詨象者より予 じか除外されている。すなわち，

1) 低音域加ら会話音城に亘る気導聴力低下が明らかで ないもの

2）正常鼓膜耳の聴力低下が軽微であるのに，異常鼓膜 耳には全音域に高度の聴力低下が認められるもの,っ まり, 騒音以外のなんらかの原因によつて感音系障害 が既に存在していると推定されるもの（第3図参照）

3）騒音曝露期間が短かく，騒音によると思われる聴力 障害がネだ認めにくいもの

4）薬物中毒, 全身疾患, 頭部外傷などの既往疾患が感 音性難聴の発来の㛬因と思われたもの

5）中耳炎手術を受けたもの

である、3）に関しての騒音懪露年数は横山27)の騒音性 難聴の進展についての統計的資料から，騒音職場経験年 数 3 年末満者は本研究対象加ら除外した, 従つて, 本研 究対象者恃以上の 5 項目を認めない騒音曝露経験 3 年以 上の片側性中耳炎を持つ者に限られた。

これら研究対象者について，純音気導および骨導聴力 検查が作業前に防音室内においてりオン製 $\mathrm{A} ・ 1002 \mathrm{C}$ 型 オージオメータを用いて常時専任の1名の検查者によつ て抽なわれた．特に骨導検査に際しては陰影聴取に注 意して必要にして十分なマスキングをおこなつた。

各症例のオージオグラムを検討するに当つて，気導， 


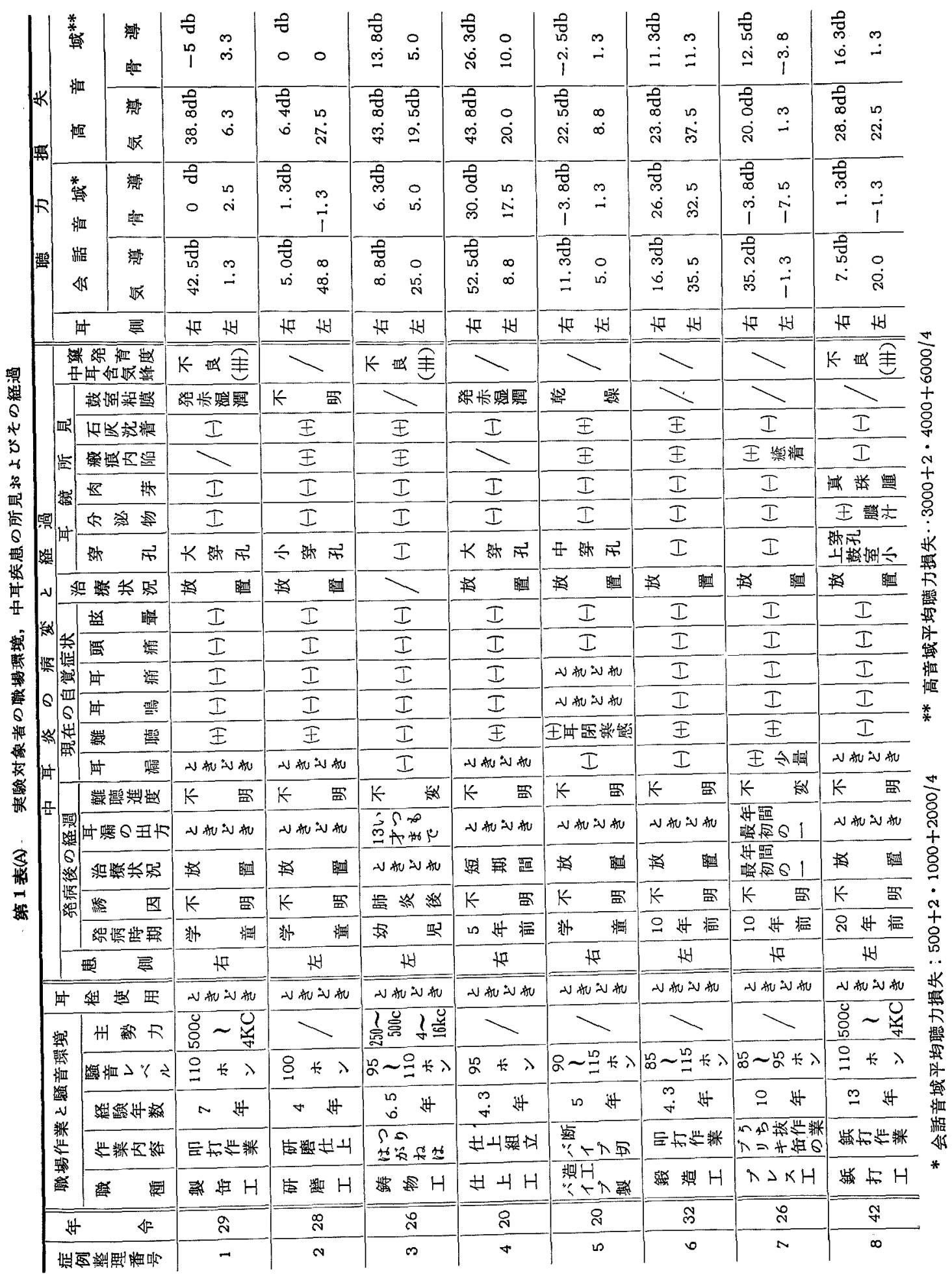




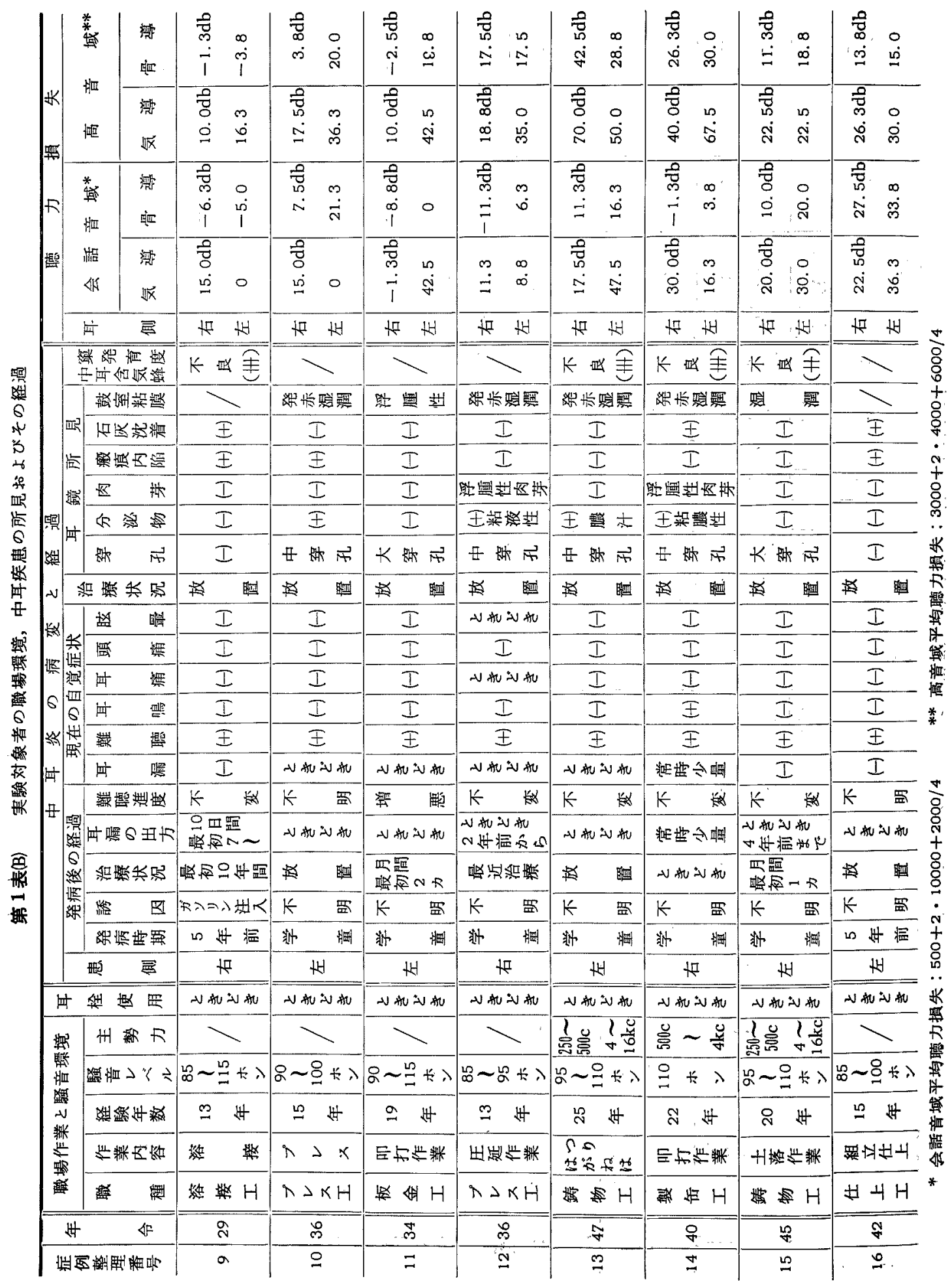


骨導オージオグラム共に，患側鼓膜耳の高音域平均聴力 損失 $(3,000+2 \times 4000+6000 \mathrm{cps} / 4)$ から健側鼓膜耳の高 音域平均鳃力損失を差し引いた值が， $-10 \mathrm{~dB}$ 以上の きは，黑常鼓膜耳が正常鼓膜耳よりも聴力良好と見做し “良好”。一9 +9dBのときは, 異常鼓膜耳と正常鼓膜 耳の聴力がほぶ等しいと見做し “不明”， $+10 \mathrm{~dB}$ 以上の ときは，異常鼓膜耳が正常鼓膜耳よりも聴力不良として “不良”と記載し，両側耳の高音域における聴力差を量 的に判定した.

なお，第 1 表に示す中耳含気蜂䆵発育度は Schüller法 によつて表わされる側頭部䗋窠群の発育度を示し，その 発育度判定は後藤（敏郎）の分類法に従つた.

また，同一個人の 6 年間の聴力変化については，今回 測定した高音域聴力損失值より 6 年前に測定した高音域 平均㯖力損失值を差し引いた值が $15 \mathrm{~dB}$ 以上あつた場合， $+15 \mathrm{~dB}$ 以上は悪化， $-15 \mathrm{~dB}$ 以上注改善と見做し， +15 $\sim-15 \mathrm{~dB}$ 末満の場合は不変とした。

\section{III 成 績}

1）症例の職場と既存の中耳炎

第 1 表注各症例の入社前後の騒音職場における作業内 容, 勤務年数, 現職場の騒音状況, 防音耳栓使用有無, 中耳炎の症状経過と現症, おょざ気導, 骨尊の音域別平 均聴力を一括して揭示したすのである。

騒音懪露年数については，本症例16名を経験年数 3 9 年 6 名, 10〜19年 6 名, 20 年以上 4 名に分類し得た. 症例整理番号はその番号の大きいほど経験年数の長いこ とを意味するむのである。

騷音の强さや周波数構成については各症例の職場騒音 の間に大差はみられなかつた。しかし職場騒音が衝撃音 加非衝撃音汃によつて本症例を 2 群に大別し得た．前者 の衝撃音曝露者には鉄材吒打作業を主としておこなう製 缶および鈑金工，スチームハンマーによる铁柱圧延作業 をおこなら鍛造工，金属板の打ち抜き作業をするプレス エ、ドロップハンマーによる抗打ち作業,鉄材落下作業や パイプ切断をおこなう作業員などが本群に属し（9名）， 後者の非衝撃音曝露者はニューマチック，ハンマーやグ ラインダーを用いての削り作業や研磨作業をする鋲打 工,釷物工，研磨工などであつて Z名がこの群に属した。

耳烃使用状況は “ときどき”之答える者が全症例にみ られた。

中耳资の発病経過については, 発病が学童期である者 が大多数で，一般に中耳炎に関する関心は薄く，そのほ とんどが治療を放置していた．鼓膜所見は16例中 4 名が
非化膿性大茅孔例， 3 名が非化膿性小穿孔例， 4 名が膿 性分泌物の䝪留または流出し鼓室の肉芽性産物や粘膜の 浮婳性変化を認める化膿性肉茅性中耳炎例（いずれも鼓 膜小穿孔または中穿孔例) で，その中の 1 名が上鼓室化 膿症であつた。残りの 5 名が鼓膜洀痕例であつた。 な お，鼓膜所見の決定には中耳炎の今までの症状経過，す なわち耳漏の有無, その多宍, 頻度などを参照して非化 膿性，化膿性に分けた。

2) オージオグラムの検誩

各症例の気導，骨導のオージオグラムは第 1，2図に 示した. 実線は患側鼓膜耳, 点線が正常鼓膜耳のオージ オグラムである. 各オージオグラムの下に記入した “良 好”, “不良”, “不明” は両側耳の高音域聴力差の程度に 前述の如き判定基準を設けこれを基にして判定したもの である.

第 2 表 異常鼓膜耳側と正常鼓膜耳側の高音域 聴力の比較

1) 気導聴力

\begin{tabular}{|c|c|c|c|c|c|}
\hline 経験年数別 & $\begin{array}{l}\text { 異常鼓膜耳の } \\
\text { 方少聴力良好 }\end{array}$ & 不 & 明 & 不 & 良 \\
\hline $\begin{array}{l}3 \sim 9 \text { 年 } \\
(6 \text { 名 })\end{array}$ & 1 名 & & 0 & & 5 \\
\hline $\begin{array}{c}10 \sim 19 \text { 年 } \\
(6 \text { 名 })\end{array}$ & 1 & & 2 & & 3 \\
\hline 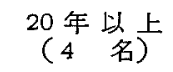 & 2 & & 2 & & 0 \\
\hline (16 ${ }^{\text {計 }}$ 名) & 4 & & 4 & & 8 \\
\hline
\end{tabular}

2) 骨道聴力

\begin{tabular}{|c|c|c|c|c|c|}
\hline 経験年数別 & $\begin{array}{l}\text { 異常鼓膜耳 } \\
\text { 方が聴力良好 }\end{array}$ & 不 & 明 & 不 & 良 \\
\hline $\begin{array}{l}3 \sim 9 \text { 年 } \\
(6 \text { 名 })\end{array}$ & 1 & & 4 & & 1 \\
\hline $\begin{array}{c}10 \sim 19 \text { 年 } \\
(6 \text { 名 })\end{array}$ & 1 & & 2 & & 3 \\
\hline $\begin{array}{c}20 \text { 年以上 } \\
(4 \text { 名 })\end{array}$ & 1 & & 3 & & 0 \\
\hline$\left(16^{\text {計 }}\right.$ 名) & 3 & & 10 & & 4 \\
\hline
\end{tabular}

先ず, 両側耳の気導, 骨尊別高音域聴力を比較した結 果は第 2 表に示した，気導聴力では異常鼓膜耳の方が聴 力悪化している者が全症例の半数を占め，その大多数は 経験年数 9 年までの者であつた，骨導聴力では両側耳の 德力がほぶ等しい者が過半数を占め, 経験年数別の関㐿 はみられなかつた。 
しかし中耳疾患の騒音性内耳障害に対する影響を知る には, 気導聴力と骨導聴力の相互の関係から検討する必 要がある. 以下，その検討結果を述べる.

症例 No. 1: 右鼓膜大呀孔のある例で第 1 図に示す如 く，正常鼓膜耳の気導は高音域に軽度の悪化がみられる 程度だが，患側鼓膜耳では全音域にわたつて $40 \mathrm{~dB}$ 前後 の悪化が認められる。しかし骨導は両側耳とも悪化はな い. 患側鼓膜耳は骨導の悪化が認められないので，気尊 の高音域低下は主に中耳伝音障害によるものと考える。 従つて，本症例の伝音性疾患注音響に上る内耳障害発生 に対して影響不明な例と考える.このような例はNo. 2, No. 5 の計 3 例あつた。 なお，No. 6 の症例は両側耳の 気導，骨導の比較では以上の 3 例と同様の結果を示すの であるが，骨尊が両側耳とも同程度に軽度低下してい る. 伝音性疾患は音響による内耳障害の発生に悪影響を 与えるかどうかについては不明な例と考える。

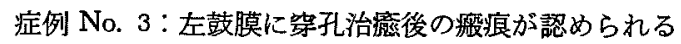
例である。患側鼓膜耳の気尊は全音域に $20 \mathrm{~dB}$ 前後の低 下がみられるが，第1 図に示す如く，骨尊の悪化注認め られない 正常鼓膜耳の高音域における気導, 骨導は共 に患側よりも強い悪化を示しているよつて伝音性疾患 は騒音による内耳障害の進展に対して抑制的に働いてい るものであるうという推定に対して肯定的知見を与える 例である。

症例 No. 13, No. 14 の 2 例に対しても同様な考え方 が可能と考える.

症例 No. 9 : 右鼓膜痴痕が認められ，5年前に右耳に ガソリンが流入してから中耳炎を来たした症例である。

第 2 図にみられる如く，2000cps 以上の気導聴力は左右 ほぐ等しく，骨導聴力においても全音域にわたつて左右 差はみられない 本症例は中耳疾患の騒音難聴に対する 影響が不明であつて, No. 15, No. 16 の 2 症例もその類 似症例である。

症例No. 10: 左側鼓膜に中案孔があり, 気導, 骨導と もにかなりの悪化がみられた例である。 その亜化程度は 第 2 図に示寸如く正常鼓膜耳に比べて大きい，本例は恐 らく騒音によつて内耳性障害が促進せしめられた症例で あるらと思われる。このような考え方のできる症例は他 に, No. 4, No. 7, No.11の計 3 例であつた.

症例No. 12 : 右鼓膜に中等度の穿孔がみられる例であ る. 本例は上述の No. 1 の例とは反対に, 患側の高音域 気導聴力が正常鼓膜耳のそれよりも良好で, 骨導は両側 耳とも高音城において同程度の低下が認められる. 本症
例は馶音曝露期間が長期で，患側鼓膜耳が正常鼓膜耳よ りも気導の高音城聴力がかなり良好であることから，卮 音性疾患が騒音性内耳障害の進展に対して抑制的作用を 示す例であろうと思う。

症例 No. 8: 本症例は気導の高音域聴力が注等しい 低下を示しているが，骨導は患側鼓膜耳の方が聴力良好 である.この症例もNo.12の症例と同様な見方をした (第1図).

以上の各症例のオージオグラムについて考察した結果 を要約すると，中耳疾患が騒音性内耳障害の発生およぴ 進展に対して㧕制的に锶いていると考えられる者は， No. 3, No. 8, No. 12, No. 13, No.14の 5 名, 逆に促進 的に作用していると考えられる者は, No. 4, No. 7, No. 10, No.11の4名, 影響不明あるいは関係がないと推定 された者は, No.1, No.2, No.5, No.6, No.9, No. 15, No.16の 7 名であつた.

第 3 表 経験年数々の関俰

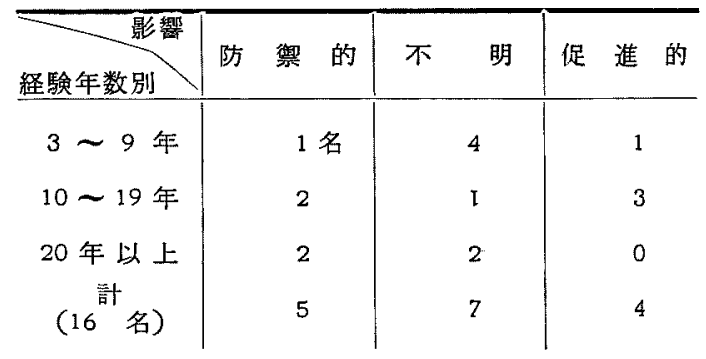

第 3 表は経験年数別に観察した結果をまとめたもので ある. 経験年数 $3 \sim 9$ 年の者は影響不明例が大多数であ り，10〜19年の者ではその半数が悪影響例であった. し かし20年以上になると内耳病変の進展を助長せしめる者 は1例もみられず, 本群の半数が好影響を示した。

次に, 鼓膜所見別に観察した結果は第 4 表に示した. 非化膿性鼓膜大穿孔例 4 名中半数は悪影響例，逆に小穿 孔または中穿孔をもつ化膿性中耳炎例 4 名は全例とも好 影響例，非化膿性小穿孔ないし中穿孔例抽よび豉膜疫痕 例は影響不明例が最も多くみられた。

次に，職場騒音の性質によつて衝撃音曝露者々非衝慗 音曝露者に大別して観察したところ，第 5 表を見て明ら かな如く，衝撃者懪露者 9 名中 4 名に悪影響がみられ， これに反して非衝撃音曝露者 7 名には悪影響 1 例も浔的 られなかつた。

さらに同一症例で 6 年前後のオージオグラムを比較し 
気 導

No. 1 (影響不明)

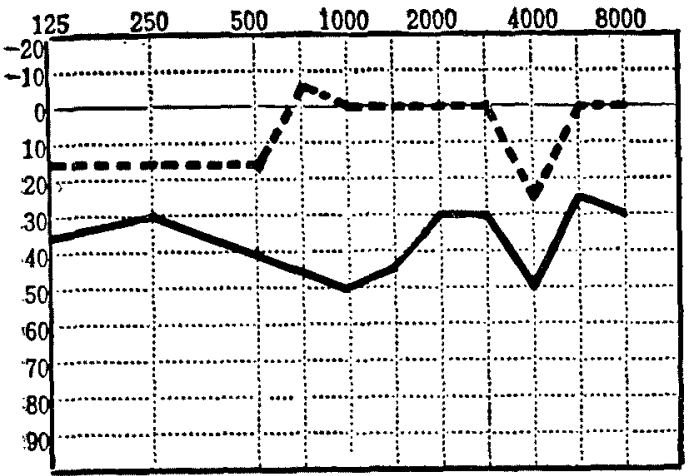

類浐症例：No. 2, No. 5, No. 6

No. 3（防缽的）
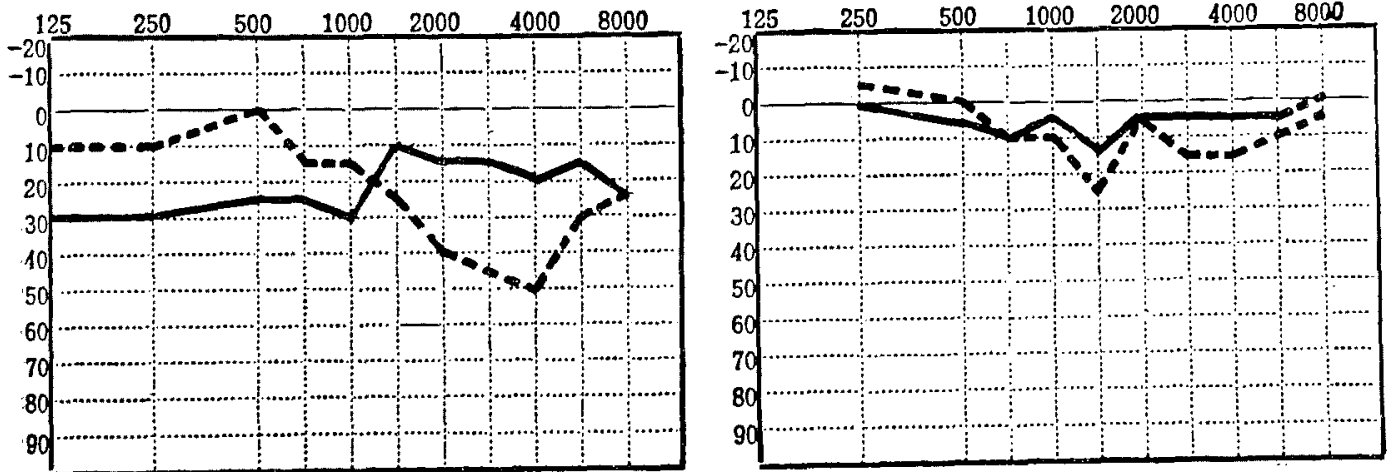

類似症例：No. 13, No. 14

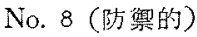
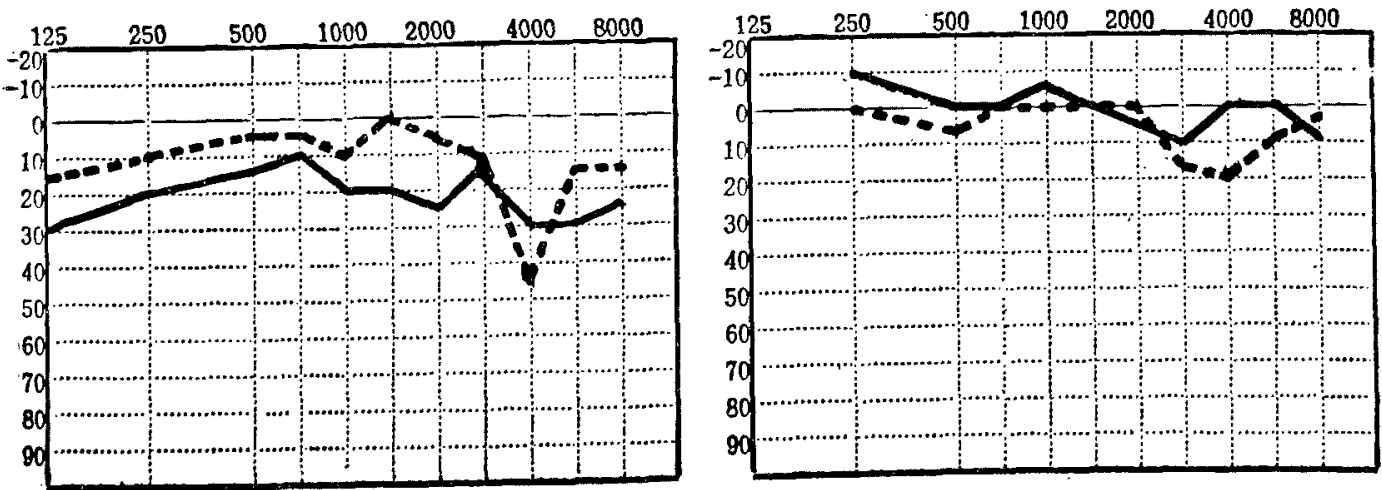

類似症例：No.12

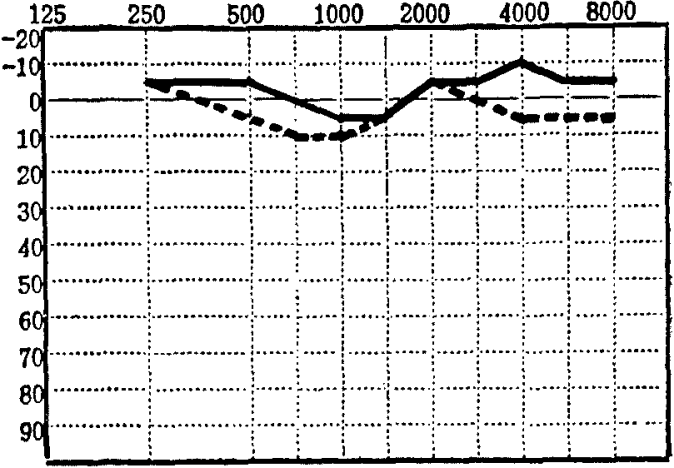


No. 9 (影響不明)
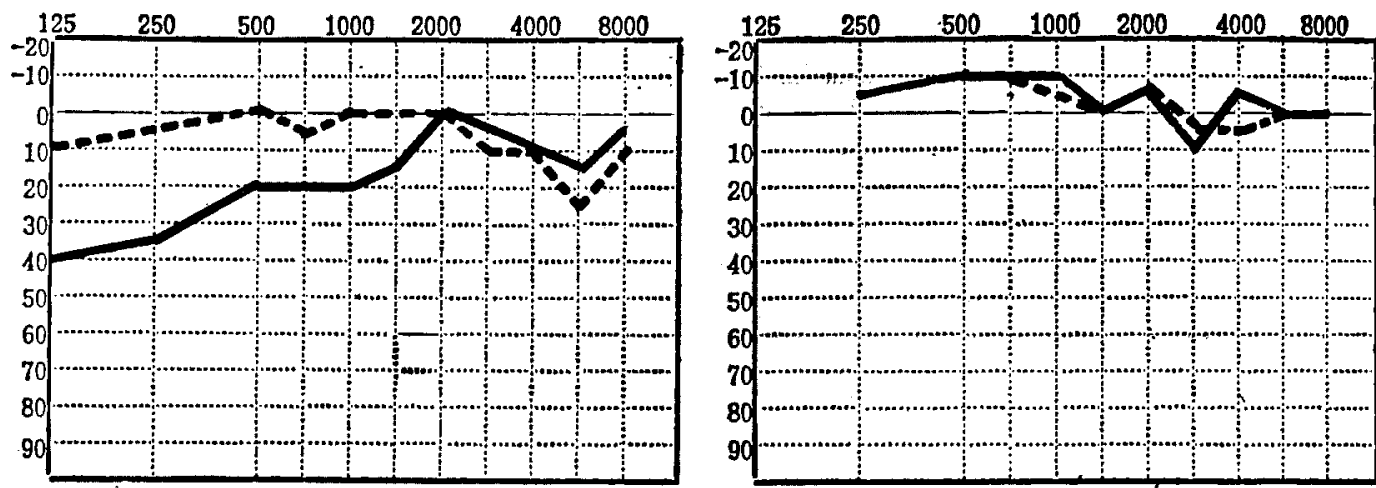

類似症例: No. 15, No. 16

No.10（促進症）
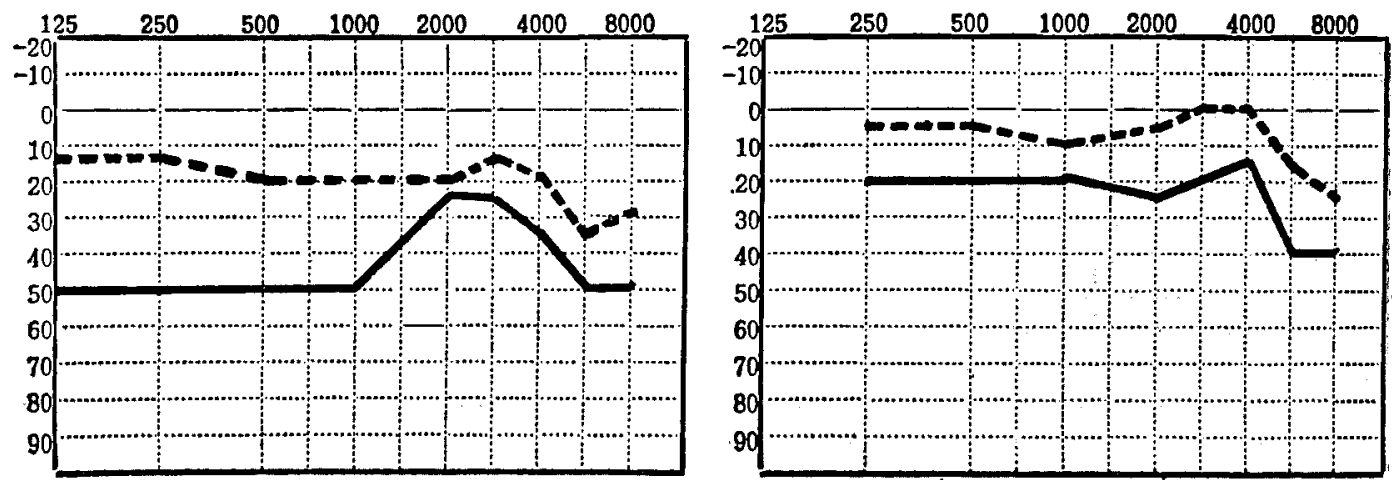

類似症例: No. 4, No. 7, No. 11

No. 12 (防禦的)
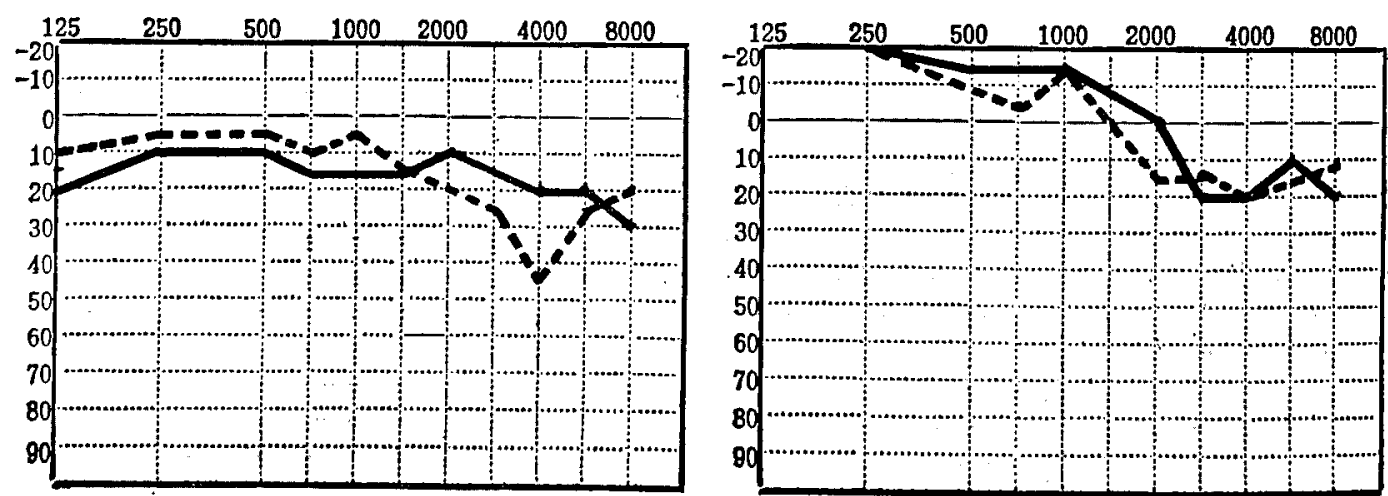

類似症例: No. 8 
第 4 表 耳鏡. 所見との関 係

\begin{tabular}{|c|c|c|c|}
\hline 鼓膜所見 & 防 権 的 & 不 & 促 進 的 \\
\hline $\begin{array}{c}\text { 非化覆性 } \\
\text { 大穿孔例 } \\
(4 \text { 名 })\end{array}$ & 0 名 & 2 & 2 \\
\hline $\begin{array}{l}\text { 化澧性 } \\
\text { 中小穿孔例 } \\
(4 \text { 名 })\end{array}$ & 4 & 0 & 0 \\
\hline $\begin{array}{l}\text { 非化澧性 } \\
\text { 中小穿孔例 } \\
\text { ( } 3 \text { 名) }\end{array}$ & 0 & 2 & 1 \\
\hline $\begin{array}{c}\text { 曒 例 } \\
(5 \text { 名 })\end{array}$ & 1 & 3 & 1 \\
\hline $\begin{array}{l}\text { 計 } \\
\text { (16名) }\end{array}$ & 5 & 7 & 4 \\
\hline
\end{tabular}

第 5 表 衝撃音曝露と非衝繋音曝露との比較

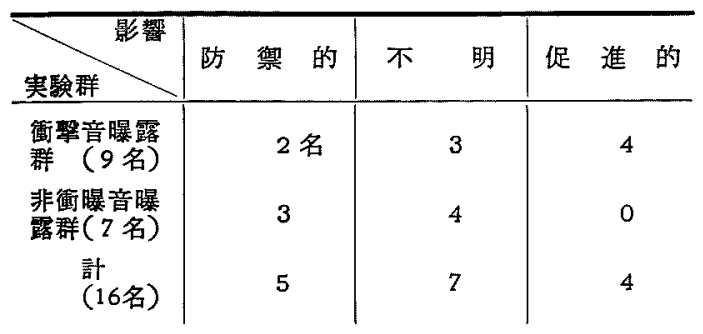

第 6 表 6 年間 9 聴力变動

\begin{tabular}{|c|c|c|c|c|c|c|c|c|c|}
\hline 症 & $\mid$\begin{tabular}{|c|} 
整理 \\
皇
\end{tabular} & $\begin{array}{c}\text { No. } \\
5\end{array}$ & 6 & 7 & 8 & 12 & 13 & 14 & 15 \\
\hline 例 & \begin{tabular}{|} 
経験 \\
年数
\end{tabular} & 3 & $\sim$ & 年 & 10 & 9年 & & 年 以 & \\
\hline 聴 & \begin{tabular}{l|} 
改 \\
善 \\
\end{tabular} & & & & & & & & 0 \\
\hline 力 & $\begin{array}{l}\text { 不 } \\
\text { 変 }\end{array}$ & - 0 & 。 & 0 & $\circ$ & - $\circ$ & - & & • \\
\hline 化 & $\begin{array}{l}\text { 悪 } \\
\text { 化 }\end{array}$ & & & & & & $\circ$ & - 0 & \\
\hline
\end{tabular}

患側鼓膜耳 。健側鼓膜耳

得た 8 名について, 高音域の気導平均聴力損失の変化を

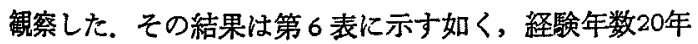
までの者では 1 耳も変動がみられなかつた，20年以上者 では, 悪化例が 2 名 3 耳, 改善例が 1 例 1 耳, 不変例 2 名 2 耳であつた。 しかし患側鼓膜耳は 3 耳中 2 耳が不 変で, 残りの 1 耳のみが健側鼓膜耳と共に悪化傾向を示 した.

\section{IV 総括および考察}

中耳は外界の可聴音域振動数を内耳に効率よく伝播す る役目をむつている.
従つて中耳伝音機構の障害は過大音響の内耳伝播を抑 制し，音響性内耳障害の発生に対する防禦的意義を失う であろうことが理論的に考えられる。しかし伝音性疾患 耳の騒音難聴に対する役割は報告書によって 異つてい る.

$\operatorname{Larsen}^{5)}$ は諸家の報告を検討して，伝音性疾患耳は騒 音性難㯖に対して，1）防禦的因子である，2）逆に感受 性を高める，3）重要性がないの 3つに大別されると述 べ，1）を考える者にSiebenman, Perlman, Sacher, Weersma，2）には Peyser，3）には Davis et al, Larsen, McLaren, and Channey などがあると述べている。 ま たChadwick ${ }^{1}$ は上述の 1)にVynckier, 2)に Novotny and Pospisil, Hoogenboom and Lansberg, Fletcher and Solomon, Schwetz, 3) $k$ Singer, Monier-Kuhn at al などを追加した. Goldner ${ }^{4}$ は造船所従業員の中から中 耳炎を有する 45 名 55 耳の平均聴力が一般の平的聴力より $13 \mathrm{db}$ 低下していることから，中耳疾患ことに鼓膜および 耳小骨連鎖の異常耳は音響に対する受倁性が高い之述心 た. Fox 拉よび Glorig3)は伝音障害は “built-in earplug” として働くと言い，音響受傷性が低いという。

本邦の文献では伝音障害が防禦的に働くといら者は藤 野22)，土肥20)。であり，萩野8) も鼓膜毞孔耳で高音域の 障害軽度であつたことよりこの説に賛同している. 立 木 ${ }^{173} 8$ 例について air-bone gap と骨導聴力損失を指 標にして伝音障害の内耳影響を検討したところ，4 例は 影響なく，3 例は防禦的，1 例は促進的に働いていると 報告した．堀 ${ }^{23}$ は 8 例の症例加ら耳栓骨導を考慮すると 伝音障害は防禦的に働く之結論した. 河内 ${ }^{9}$ は 9 例の第 孔性中耳炎を有する抗内夫の資料より，騒音は既往の哿 孔性中耳炎側の内耳に影響を与えないが，職種(整岩員) によつて促進的な影響を与えると述べている．富永 ${ }^{29}$ 汢 鼓膜洀痕耳および穿孔耳は勤務年月 15 年以上になると。 健常耳より高音域に障害の少ないものが増加し, 土肥の 鼓膜異常耳についての成績と全く一致したという。

これに対し江口6) は製缶工場作業員で穿孔鼓膜耳は， 経験年数 18年前では非穿孔鼓膜耳より難聴は軽度である が，それ以上になると逆に穿孔鼓膜耳の方が高度になる ように思われたと述へ，富永，土肥らの見解と一致をみ ない。

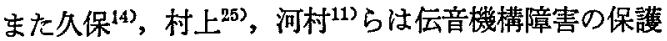
作用を否定している.

私共の本研究対象者16名の気導聴力に骨導聴力を加味 して検討した結果によれば，中耳疾患は騒音性内耳障害 
の進展に抑制的に働いていると思われる例が 5 名, 促進 的に働いていると思われる例が 4 名, 影響不明が 7 名 で，全体的には一定の傾向は認められなかつた。

しかし，経験年数別に観察すると，20年末満では促進 的と思われる例が最も多く，殊に10 19年 6 名の中 3 名 に本例がみられた。 これに対し20年以上の者には促進的 と思われる例が 1 名も認められず, 抑制的と思われる例 が 4 名中 2 名, 影響不明例が 2 名であつた.

以上の如く, 騒音性難聴に併存寸る伝音性疾患が内耳 に対して如何なる態度をとるかについて諸家の意見に一 致をみないことは，本問題に下記の如き種々の要因が関 与することに原因があるものと思 5. (1)本問題の研究対 象になり得る症例が極めて少ない. (2)伝音性疾患自体に よる内耳性障害併発の問題, (3)職場騒音の強さと性質, (4)個人差，(5)騒音曝露経験年数などである.

(1)の研究対象が少ないことは統計的に明確な結論が下 しにくく，また少数例のために症例の撰択条件，成績判 定の基準のとり方によつて研究結果が相当に変る.

(2)関しては Goldner" は Trowbrige の “鼓膜は音 伝導よりも過大音に対する防禦機構に関係する”と言う 説に注目し，中耳病変の中でも鼓膜紫孔，耳小骨連鎖不 全が内耳の音響受賃性を六進することを強調した. 久 保 ${ }^{177}$ は鼓膜変化の程度の強度なもの程高音域平均聴力低 下の大なる率が多く, 特に案孔の存在するものに顕著で あると記述し，Peyser ${ }^{15)}$ は耳小骨筋の防禦機能を重 すると共に, 肉芽性変化を有する化膿性中耳炎洔特に音 響受傷性が高いと聴覚疲労実験から立証した. 河田 ${ }^{12}$ は 耳管および耳小骨筋の機能異常を後天的聴器音響受傷亢 進の成因の一つとして重要視している。

中耳含気蜂窠発育抑制も聴器音響受傷性を高めること が Link Diament, Janko によつて報告されている，以 上の諎家の報告を綜括すると, 中耳病変殊にその強度な ものは内耳の音響性障害が大きいといら意見が強い，私 共の症例に招いては, 第 4 表に示寸如く, 鼓膜瘄痕例の 5 名ではその大部分が兩側聴力に差がなかつたが, 非化 膿性大穿孔例 4 名についてはその中 3 名は患側故膜耳の 方が高音域低下が大であり，他の1名のみが両側聴力に 差が認められなかつた。 また，鼓膜小紫孔または中呀孔 を有し, 膡性分泌物之鼓室内の炎症性変化が認められる 化膿性中耳炎例の 4 名では, 全例とも患側鼓膜耳の方が 聴力良好で，Peyserの報告と逆の結果が得られた、しか し鼓室内に分必物眝溜を認める症例は聴力検査時の分泌 物の程度, 性質および貯溜部位によって聴閵值がかなり
変動することがあるのでその判定には慎重を要する。 (3)の慢性中耳炎例に高音城骨導の短縮を示す場合のあ ることは古くより知られていた。 堀口と角田 ${ }^{24}$ は慢性中 耳炎163例の中で4000および8000cps 高音域聴力損失例が その 3 分の 1 を占めていたと述べ，中耳炎の内耳侵熋 時期は中耳炎罹患当初加ら起ると報告した. 立木 ${ }^{183}$ は中 耳病変と聴力との関聯性を調へ，慢性中耳炎の高音域骨 導低下は中耳病変の高度なものに多く, 特に鐙骨の消 失, 不明または内耳空部に病変が認められるものにその 程度が著明であつたと述べ，神尾と荒田 ${ }^{100}$ は約30例の乳 様洞骨壁の病理学的所見から, 慢性中耳炎における骨導 低下は乳様洞骨壁の炎症が内耳骨壁を経て内耳儿波及す ると考えている。教室の山本ら ${ }^{26)}$ の慢性中耳炎 102 耳の 鼓室内病変と聴力との関係を検討した報告書によれば, オージオグラムの水平型, 山型などの高音域聴力の低下 を含む障害型䄧よび高音域限局障害型を示すものが, 全 例の大部分を占めており, 骨導の高音域障害でも33\%が 発見されている. 山本らは慢性中耳炎の聴力は耳小骨連 鎖の有無および中耳伝音機構代償の有無, さらに両内耳 空運動障害の如何によつて大きく規定されるものであ り，内耳への障害波及はより著明な聴力障害をもたらら すと述べた. 伝音性疾患の高音域低下の原因として，そ の他内耳の障害なしに伝音機構の変化による高音域聴力 の悪化もあり得るとの考えが一部の研究者 ${ }^{773116)}$ によつ て報告されている.

このように伝音性疾患自体によつて高音域障害が高率 に出現するのであるならば，慢性中耳炎を有する騷音職 場長期勤務者の高音域低下は，騒音によるものか中耳炎 によるものか判定を下すことは容易でない，中耳炎によ る高音域低下と騒音下における中耳炎耳の高音低下との 間でその聴力像に特異的な差があるか否かが問題となる が，これ忚両者共多数例をもつて比較検討しないと結論 を得ることは難しい

第 3 図は健側亄膜耳の聴力が正常または軽度障害で, 患側鼓膜耳の気導, 骨導が高度に低下し, 気導では全音 域平均 $60 \mathrm{~dB}$ 前後の聴力損失を認めた症例の各オージオ グラムを一枚の用紙に記入したものである. 中耳炎耳で $60 \mathrm{db}$ 以上の高度難聴例は山本 ${ }^{262}$ らの102耳の中で 13 耳発 見されたが，私共の調查した駩音下従業員の慢性中耳炎 例 40 耳の中では 7 耳も検出され，症例の大部分が㪍膜大 玡孔例であつた。

騒音下従業員の中耳炎罹患耳に高度難聴例が多数に出 現したことは非常に興味ある事実でっここれは恐らく中耳 
第 3 図 騷音職場従業員の高度難聴中耳炎症例

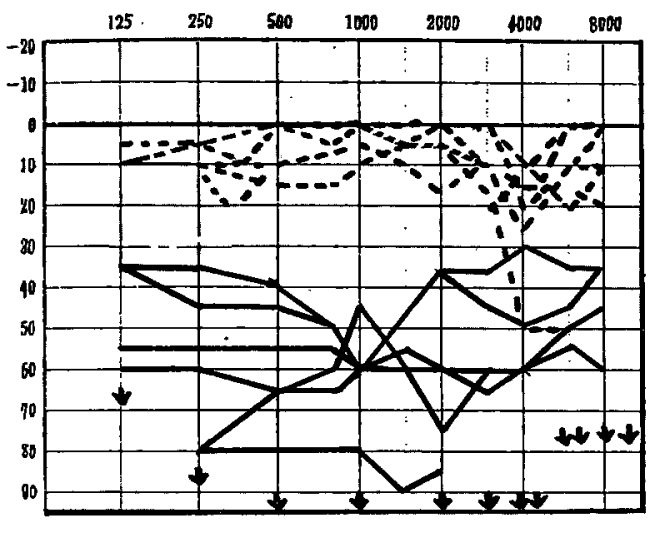

患側鼓膜耳

炎から内耳障害が㟟起されると，騒音刺戙がこれに相 加，相乗してさらに内耳障害を増強せしめるのではない かと推察される. 以上の推論を明確にするには, 騒音職 場就業前の聴力と照合すると共に，中耳病変, 他側聴 力，騒音の強さと性質，および経験年数などとの関聯性 を詳細に検討する必要があり，今後これらの点について の野外調査および実験的研究をおこなつて明らかにした いなお，これらの症例は本研究対象者よりも高度な聴 力低下を来していること，その原因が不詳であることな どから，今回の研究調查と別個に取扱つた。 Dieroff"'は 伝音障害耳の多くは職業性難聴を防禦するが，明らかな 高度の内耳障害を示寸伝音障害耳もみられるので, 実際 上の騒音職場の適, 下適の判断は定期的聴力検查でなさ れるべきであると記述しているよらに，伝音性障害の騒 音性難㯖に対する影響は個々の症例によつて異なる訳で あるから，本症例に対する聴力管理恃個人管理が必要で あると考える。

(4)の騷音の強さとの関聯性については, Chadwick ${ }^{1)}$ は jet engine 騷音下勤務者12名と steam turbine engine 騷音下勤務者12名の聴力达比較観察し, 後者の騒音が比 較的小さな職場勤務者障害耳には騒音に対する防禦効果 がみられるが，前者の強大騒音職場勤務者の中耳障害耳 は正常鼓膜耳よりも聴力低下していると述べ，これは騒 音の強さがある程度以上になると防禦効果がなくなり， 蝸牛機能の障害が堌強するのであるらとと推測した，久 保 ${ }^{14)}$ は生理的中耳制音機構は比較的弱く，4000cps，100 ホン以上の強大音に対しては殆んど保護効果はないと考 えている! 本調查各職場の騒音の強さ, 周波数構成には

特記すべき差がみられなかつたので，この点に関しては 考察を加えることはできなかつた．私共は各職場を衝撃 音懪露環境と非衝撃音懪露環境に大別して，衝擊音懪露 の有無の面より本問題を検討した，その結果は第 5 表に 示す如く，慢性中耳炎が騒音性難聴を促進的に㗢いたと 思われる例の 4 名が衝撃音曝露環境の従業員からす心゙て 発見され，非衝撃音曝露環境に㗢らく従業員には本例が 1 名むみられなかつた。

瞬時的に高度の音圧上昇を来たす衝撃音は中耳伀音機 構障害があつても，過大音エネルギーは容易に内耳え伝 播されるのかも知れない：この点に関しては後日さらに 研究を重ねて明らかにしたい。

その他の職場環境との関係として, Temkin ${ }^{6)}$ は片側 性慢性化膿性中耳炎を有する作業員の両側聴力を比較し たところ，両側耳の聴力差は中耳疾患の性質ばかりでな

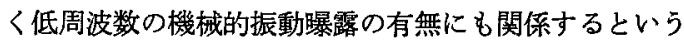
興味ある報告をしている. 上述の非衝教音曝露従業員は ニューマチック・ハンマーや, グラインダーなどの手持 振動工具を用いての長時間作業をおこなつている者ばか りであるが， 7 名の中耳炎罹患耳が騷音性難聴の進行に 対して促進的に作用していると思われるものは1例もみ られず, Temkin と相反した結果が得られた。

(6の騒音職場経験年数との関係であるが前述の如く， 報告者によつて意見が異なる. 私共の症例では, 程験年 数10〜19年者の中の半数に内耳に悪影響が与えるが，20 年以上者には悪影響例が 1 名も認められず，反対に好影 響例がその半数も占めていた．従つて䭷音職場に長年月 間勤務していると，伝音性疾患は内耳保護作用を有する ように思方九る。 しかし，経験年数 20 年以上者の大多数

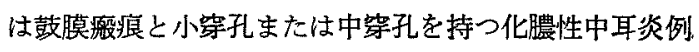
であつて，上述の如き内耳悪影響例の多い大穿孔例が 1 名しか含まれていないことから, 以上の症例数だけで最 終的結論を下すことは難しい．

さらに私共は 6 年間の継続して検查し得たオージオグ ラムを比較し得た 8 名の症例について, 両側耳, つまり 患側鼓膜耳と健側鼓膜耳 96 年間における聴力変化を観 察した。 その結果は第 6 表に示す如く, 経験年数20年以 下の者ではその全例が両側耳とも聴力変動が認められ ず，20年以上者においてはその全例が聴力変動を示し， その変動耳の大多数が.健側亄膜耳であつた．私共 ${ }^{28}$ は両 側中耳炎霍患者を含めた 18 耳の 6 年閒聴力変化を今回と 同様な方法で観察したところ, 聴力増悪例が 18 耳中 8 耳 も認められ，その出現頻度は健常臌膜をもつ実験群のを 
れに比べて約 3 倍の高率であつたことを報告した。これ は今回の調查結果とまつたく相異つた結果であるが，今 回の調査結果は同一個人の左右耳を比較したものであ り, 前回の調査結果は実験集団の異つた中耳゙炎篗患群と 中耳炎非䍜患群の成績を比較したもので，厳密な意味で の両調查報告の比較は困難である、騒音下における中耳 炎罹患耳の難聴推移を長期閒にわたつて観察することは 測定誤差, 测定時の中耳炎の状態などの因子が加つて， 内耳障害を知ることが中耳炎非罹患耳に比べて一層難し いと思われる。

明確な結論を下すには，なお多数の症例について聴力 榆查を習熟した検查者によつて同一条件下で長期間しか も頻回に絽返し測定する以外に方法はないものと考え る.

私共は16名の症例について, 中耳疾患と騒音性難聴と の関聯性を知るために，上述したよらな各要因別観察を おこなつたが，例数不足のために決定的な結論を得るこ とはできなかつた，さらに例数増加につとめ，上記の不 明な諸点を追求したい

\section{$\mathrm{V}$ 結 語}

騒音職場経験年数 3 年以上の片側性慢性中耳炎を有す る騒音下従業員16名について，慢性中耳炎が騒音性内耳 障害に対して如何なる態度を示寸かを種々の面より考察 し次の如き結論が得られた。

1）気導㯖力だけでは，患側鼓膜耳の方が健側鼓膜耳 よりも聴力悪化している者が全例の半数を占めていた。 その大部分は経験年数 10 年末満者であつた. 20 年以上の 者には,このよ5な聴力悪化例は全く認められなかつた.

2）骨遵㯖力の低下を重視して検討したところ，騒音 性内耳障害に促進的に衝いていると思われる例は 4 名, 逆に防禦的と思われる例は 5 名, 影響不明は 7 名であつ た. 促進的と思われる例は全て経験年数20年までの者, 20年以上者には発見できなかつた.

3）鼓膜所見別に観察すると, 非化膿性大案孔例 4 名 中 2 名が悪影響例, 他の 2 名が影響不明例であつたのに 対し，小穿孔または中穿孔を有する化膿性中耳炎例の全 例が好影響を与えたことから，前者は内耳の音響受傷性 を促進的に, 後者は防禦的に働らくのではないかと考え た. また，非化膿性小穿孔および中穿孔例および鼓膜洀 泿例は影響不明例が最も多かつた。

4）経験年数 20 年以上者に促進例が 1 名も認められな かつたが, 本群の大多数が鼓膜症痕例および小穿孔また は中紫孔を有する化膿性中耳炎例であつたので, 最終的
結論を下すにはさらに多数の各種症例について慎重に検 討を加える必要があると考えた。

5）各症例の職場騒音の強さおよび周波数構成が類似 していたので, 騒音の強さおよび周波数構成別観察はで きなかつた。しかし常在性騒音が衝撃音か否かによっ て, 研究対象者を衝摮音曝露彷業員と非衝慗音曝露従業 員に大別し得た。 その結果, 前群の従業員 9 名中の 4 名 が騒音性難聴促進例であつて, 後群の従業員 7 名の中に は促進例は 1 名む認められなかつた。

6）今回測定したオージオグラムと 6 年前に測定した オージオグラムを比較し得た 8 名の症例について, 過去 6 年間の聴力変化を個人別に観察した。その結果, 経験 年数20年までの者では両側耳とも変動は認められず, 20 年以上の 3 名はすべて変動が認められ, その大多数が健 側鼓膜耳であつた。

7）患側鼓膜耳聴力が健側鼓膜耳聴力に比して全音域 にわたり $60 \mathrm{db}$ 前後の高度の低下を示した 例が研究対象 職場従業員から 7 名検出された. 両側耳の聴力差が非常 に高度であること，騒音懪露経験年数が比較的短いこと などの理由で本研究対象者16名と別個に取扱つた，高度 聴力低下は騒音による障害と既存の中耳炎の内耳障害の 併発による可能性が大きいと推定した.

8）これら症例 7 名の聴力像加 , 既存の中耳炎が内 耳障害を惹起し，これがある程度進行すると，騷音刺载 がこの内耳障害をさらに促進せしめるのではないかと推 定し，今後検討を要する症例と考えた。

\section{主要文献}

1) Chadwick, D.L.: Acoustic trauma-Some investigations concerning industrial noies. J. of Laryng. \& Otol.. $77 ; 467,1963 . \quad$ 2) Dieroff, G.: Die Schalleitungs-schwerhörigkeit als Lärmschutz. Zeitsch. f. L-RO. $43 ; 690,1964 . \quad 3)$ Glorig, A. . Noies and your ear. Grune \& Stratton, New York, 1958.4 4) Goldner, A.L.: Deafness in shipyard workers. Critical evaluation of finding in six hundred cases and diagnosis of occupation deafness. Otoalryng., $57 ; 287$, 1953. 5) Larsen, B.: Occupational deafness. Acta Otolaryng.. 41；139，1952. 6) 江口 茂：穿孔鼓膜 の職業性難聴, 日耳鼻, $58 ; 1068,1955$ (昭30). 7) 萩野 尚：音響附自形式の鼓膜穿孔耳聴力飞括よ注す影 響炕関す万研究。日耳鼻，69；2004，1967 (昭42).

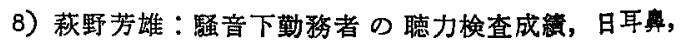
$61 ； 239,1958$ (昭33). 9) 河内一郎：抗内夫の聴力 
梌查成稹. 耳喉，34；247，1962（昭37）。10）神尾 交彦, 荒田節男：慢性中耳炎の骨病理と骨導低下. オ一 ジオ, 6；174，1963 (昭38). 11) 河村進市：音響性 㯖器外㘯の臨床的観察. 级害医学, 6；59，1958（昭33） 12) 河田政一：後天的音暗性外傷受伤性とい3考克。耳 々臨, 6；3，1957 (昭34). 13) 切替一郎：伝音機構 と骨導阔する基礁的研究. 日耳鼻，60；386，1957(昭 32). 14) 久保正雄: 交通事業に和污騒音性難聴の 実態とその対策，第16回日本医学会総会講演別刷。1963 (昭38). 15) 後藤敏郎: Pneumatization の成立とそ の臨床. 日耳鼻, $57 ； 1028,1951$ (昭29). 16) 立木 孝: 骨尊聴力関する一考察. 耳㬋，26；97，1951（昭 29). 17) 立木 孝他：騒音性難聴飞拈よほす寸既存の 会音障害の影響についての一考察, 耳喉, 35；625, 1963 (昭38). 18）立木 孝：慢性中耳炎飞挌ける 鼓室内 病変と聴力との関聯について. 耳㬋, 39；921，1967(昭 42). 19）富永泰栄，阿部弘之：騒音が伝音系疾患に

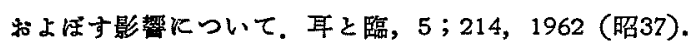
20）土肥勝利：鼓膜の異常が職業性難聴に及洔寸影響に ついて。 日耳鼻, $56 ； 545,1953$ (昭28). 21）萩野 芳雄：騷音下勤務者の聴力検查成嘖. 日耳具，61；239, 1958 (昭33). 22）藤野彦四郎：職業性難聴飞関する 知見補遣. 日耳䋈，53；19，1950（昭25）。23）堀
昭蜼：騒音性難㯖器障害と中耳公音機構の熊度との関係 耳喉, $29 ; 605,1957$ (昭32). 24) 堀口申作, 角田 志信：慢性中耳炎の聴力像について。 日耳年，56；807， 1953 (昭28). 25) 村上隆德 : 機関車乗務員の聴力火 ついて (第 2 報), 日耳鼻，8；1412，1956 (昭31).

26）山本䜿他：慢性中耳炎の鼓室内病変と聴力との関 係. 耳鼻臨，52；951，1959 (昭34). 27) 横山俊彦: 騒音性難㯖に関する研究（第 2 報）騒音性難聴の気尊才 一ジグラムの統計的処理法について。 日耳鼻，66;77 1963 (昭38). 28）横山俊彦他：同一騒音下従業員の 聴力関する長期的観察. 日耳鼻， $71 ； 5 ， 1968$ (昭43 年 5 月掲載予定)

稿を終るに臨み御校閲を頂いた恩師山本賢教授に 梁謝します。

本論文の要旨は第 41 回日本産業医学総会（新渴， 昭和 43 年 5 月）和上び日本耳楀咽唉科学会大阪地方 会第117回 例会（昭和38年 2 月）, 第118回 例会 (昭 和38年 5 月)，第142回例会（昭和43年 3 月）飞おい て演述した。

（原稿受付 昭和43.6.8日） 